\title{
The impact of anthropogenic and external influences on the life cycle of a real estate object in Vietnam
}

\author{
Maria Matveeva ${ }^{1, *}$, Olga Larina ${ }^{1}$, and Hai Yen Pham ${ }^{2}$ \\ ${ }^{1}$ Irkutsk National Research Technical University, 664074, Lermontova str., 83, Irkutsk, Russia \\ ${ }^{2}$ Trade and Construction Company No 6 Ltd, Street 23/335, Quarter Tan Than, Dienbien, Vietnam
}

\begin{abstract}
The life cycle of real estate objects in Vietnam have been studied in the terms of negative anthropogenic and external impacts. It is shown in the paper that the reliability and longevity of the constructed objects are influenced in aggregate by all groups of the impact factors considered with the disclosure of the destructive processes leading to collapse of the buildings. It is explained that in order to ensure the safety of functioning of buildings erected in compliance with regulatory requirements at the stages of their construction and operation, it is necessary to conduct constant monitoring of their actual technical condition.
\end{abstract}

According to statistics, currently, in Vietnam and other countries of the world, there are still cases of collapse of buildings, including at the stage of their construction, causing material damage and human casualties. Thus, in Russia, according to the Ministry of Emergency, four cases of collapse of buildings occurred only in the first nine months of 2017 [1]. Similarly, according to the available information, in Vietnam in 2017, eight buildings collapsed, with the death of two people, and six people were injured [2, 3]. Earlier, in 2016, seven buildings collapsed, as a result of which eleven people were killed and seventeen were injured $[2,4]$.

In the causes of the collapsed buildings, errors previously committed at each stage of the life cycle of the constructed buildings and structures were revealed. The main ones are the following:

- mistakes made during engineering surveys;

- mistakes made at the stage of designing;

- use of low-quality materials, products and structures;

- deviations from the rules and norms when performing construction and installation works;

- existence of unfair competition in construction when concluding contracts and purchasing materials;

- deviation from the rules of maintaining buildings during their operation, etc.

Understanding the causes of the collapse of buildings allows developing measures to reduce material losses and prevent tragedies in connection with the death of people in case of accidents, as well as identifying critical defects and choosing the correct ways to prevent

*Corresponding author: expertiza@ istu.edu 
their development. However, the presence of a wide range of destructive factors makes it difficult to establish the actual causes preceding the onset of an emergency condition of buildings. Based on the nature of the impacts that caused the collapse of buildings and structures, their classification according to two types of impacts - anthropogenic and external - is suggested. The composition of destructive factors in these areas is shown on the Figure 1.

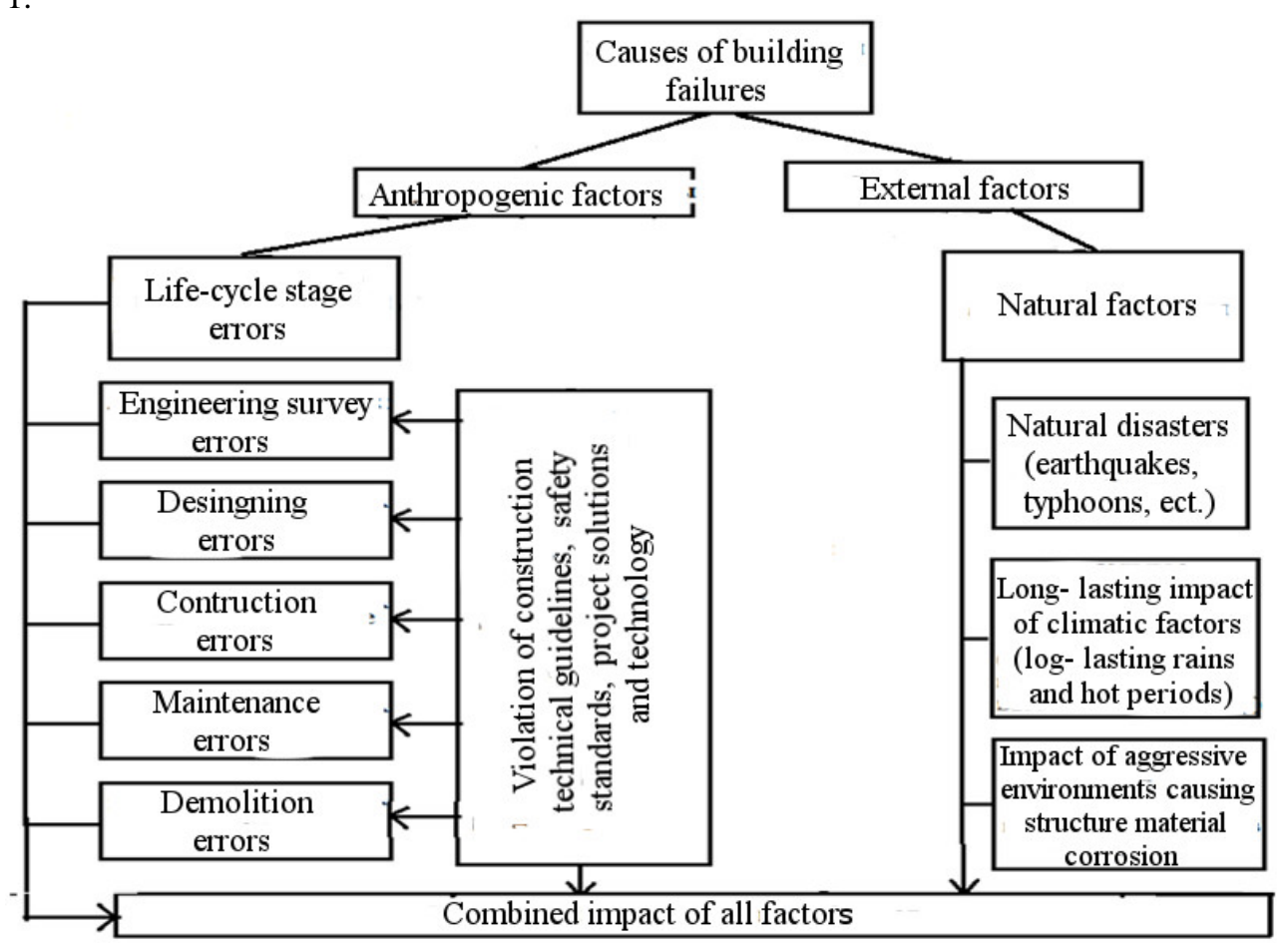

Fig. 1. Classification of the causes of collapse of buildings.

The collapse of buildings, depending on the duration of the defect accumulation and the development of deformations, occurs mainly in two options: either with their gradual accumulation and subsequent collapse, or quickly and at one moment in unpredictable time. According to Russian practice, cases when buildings those were in a safe state and which had no visible defects after many years of their exploitation, suddenly collapsed, were not uncommon [5]. The joint effect of destructive factors is a possible cause for this, the development of which is associated with violations committed at the stages of engineering surveys, design, construction and operation of buildings. The revealed violations committed at all stages of the life cycle of construction objects with the manifestation of their consequences and examples of the destruction of buildings are presented in the Table 1.

Table 1. Violations committed at all stages of the life cycle of construction objects with the manifested consequences and examples of destruction of buildings.

\begin{tabular}{|l|l|l|}
\hline Stages & \multicolumn{1}{|c|}{ Violations committed } & \multicolumn{1}{c|}{ Implicated consequences } \\
\hline & $\begin{array}{l}\text { The quality of engineering surveys does } \\
\text { not meet the established requirements } \\
\text { (the number and depth of drilled wells, }\end{array}$ & $\begin{array}{l}\text { The incompleteness of data on the } \\
\text { geological structure of the soil under the } \\
\text { foundation of the future building (the } \\
\text { presence of individual sections of the soil } \\
\text { the quality of drilling equipment, the } \\
\text { quality of the samples analyzed). }\end{array}$ \\
& $\begin{array}{l}\text { including lenses of weak soils, as well as the } \\
\text { impact of karst-suffusion processes with the }\end{array}$ \\
\hline
\end{tabular}




\begin{tabular}{|c|c|c|}
\hline & & $\begin{array}{l}\text { formation of failure funnels in the area of the } \\
\text { building). }\end{array}$ \\
\hline & $\begin{array}{l}\text { Absence of the forecast of geotechnical } \\
\text { changes in the soil and groundwater } \\
\text { level, as well as data on tectonic } \\
\text { processes of the area }\end{array}$ & $\begin{array}{l}\text { Violation of the stability of the foundations } \\
\text { of buildings and the development of } \\
\text { geological processes in the soil (landslides, } \\
\text { landslides and collapse). }\end{array}$ \\
\hline & $\begin{array}{l}\text { Absence of analysis of data on } \\
\text { geological survey of the territory of the } \\
\text { nearest buildings. }\end{array}$ & $\begin{array}{l}\text { Destruction of the foundation of the existing } \\
\text { building due to the development of uneven } \\
\text { additional subsidence caused by the nearby } \\
\text { building under construction. }\end{array}$ \\
\hline \multirow{4}{*}{ 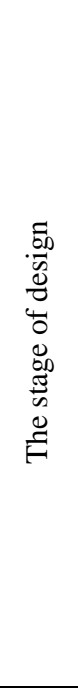 } & $\begin{array}{l}\text { Errors in calculating soil subsidence } \\
\text { and in choosing a constructive scheme } \\
\text { of the foundation of buildings. }\end{array}$ & $\begin{array}{l}\text { Lead to unacceptable subsidence and roll of } \\
\text { the building, the opening of cracks in the } \\
\text { walls and its destruction. }\end{array}$ \\
\hline & $\begin{array}{l}\text { Replacement of load-bearing structural } \\
\text { elements during capital repair of the } \\
\text { building on structures with lower } \\
\text { bearing capacity, or their dismantling. }\end{array}$ & $\begin{array}{l}\text { Violation of the joint working capacity of } \\
\text { load-bearing elements of the building and } \\
\text { the development of critical defects leading to } \\
\text { a decrease in the service life of the building, } \\
\text { or its collapse. }\end{array}$ \\
\hline & $\begin{array}{l}\text { The lack of an assessment of the effect } \\
\text { of the erected building on the foundation } \\
\text { of a nearby one without precautionary } \\
\text { measures against its additional } \\
\text { subsidence. }\end{array}$ & $\begin{array}{l}\text { Uneven sedimentation of existing buildings } \\
\text { with the formation of through cracks and } \\
\text { subsequent collapse. }\end{array}$ \\
\hline & $\begin{array}{l}\text { Errors in the assignment of loads and } \\
\text { reliability factors in calculations of } \\
\text { load-carrying capacity of structures. }\end{array}$ & $\begin{array}{l}\text { Overloading of load-bearing structures, } \\
\text { especially floors and ceilings, when used for } \\
\text { storing building materials, structures and } \\
\text { equipment during construction of a building } \\
\text { and placement of working equipment during } \\
\text { operation. }\end{array}$ \\
\hline \multirow{3}{*}{ 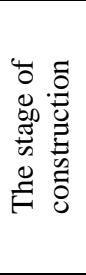 } & Use of poor-quality materials. & \multirow{3}{*}{$\begin{array}{l}\text { Reducing the load-bearing capacity of } \\
\text { structures to be erected and the development } \\
\text { of destructive deformations leading to loss } \\
\text { of reliability and safety of operated } \\
\text { buildings. }\end{array}$} \\
\hline & $\begin{array}{l}\text { Deviation from design solutions. } \\
\text { Violation of the requirements of } \\
\text { regulatory documents in the } \\
\text { organization and production of works. }\end{array}$ & \\
\hline & $\begin{array}{l}\text { Lack of proper control over the progress } \\
\text { of work. }\end{array}$ & \\
\hline 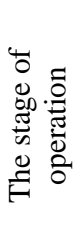 & $\begin{array}{l}\text { Violation of the rules of operation and } \\
\text { maintenance of buildings. } \\
\text { Untimely and substandard repairs. }\end{array}$ & $\begin{array}{l}\text { Emergency condition of underground } \\
\text { communications and sanitation systems. } \\
\text { Reducing the load-bearing capacity of } \\
\text { foundations and changing soil properties. } \\
\text { Decrease in operational characteristics of } \\
\text { structures of the aboveground part of } \\
\text { buildings. }\end{array}$ \\
\hline
\end{tabular}

The collapse of buildings, the facts of which are given below, became the consequence of the mistakes made at the stages of engineering surveys, design, construction and operation of the built objects.

In 2007, in the city of Ho Chi Minh, in the construction of a multi-story building, due to the lack of data on the presence of groundwater in the excavation level, the subsidence of the road with the formation of a funnel with an area of $32 \mathrm{~m}^{2}$ and a depth of $1.6 \mathrm{~m}$, as well as subsidence of the foundation of the nearest apartment building 5 Nguyenyishu Street at 120 mm occurred [6].

In September 2017, a four-story apartment building 43 Tanshonhoa Street collapsed in the city of Ho Chi Minh, which caused the consecutive destruction of two other nearby residential buildings - six-story building No. 45 and No. 47, and damage to the walls of the 
building No. 49. The reason was the work of the excavator making construction pit for the building No. 41 (under construction) with the depth of foundation below the foot of the existing foundation of the building No. 43. According to the conclusion of the examination, the developer of the building No. 41, without having studied the data on engineering and geological surveys of the areas adjacent to the construction site, failed to perform protective measures in relation to the foundation of a nearby building [7]. For a similar reason, in 2017, in the city of Bindin, when a pit was excavated for the building No. 298 under construction, a building No. 296 collapsed with severe consequences, as one person died and three were in heavily injured [8].

In 2011, in the city of Hanoi, the building No. 49 on Khuin Thuhang Street collapsed after its reconstruction. The reason for the collapse is associated with the replacement of loadbearing walls made of bricks on the ground floor of the building with glass, and installation of a reservoir for collection of rainy water on the sixth floor. The unreasonable design decisions have caused an overload of bearing walls and building constructions and its collapse [9].

In 2015, in a dead end Ledinkan, Tantao Quarter of Shaigon, an industrial two-story building collapsed. As a result, two people were killed and seven were injured. The reason was overloading of the floor of the second story of the production room with a load higher than the one envisaged by the design [10].

Buildings collapse even in the process of their construction because of the mistakes made at the two previous stages of their life cycle.

An example of this is the collapse in 2014 of the four-story building on the street No. 66 of the Futan Quarter of the city of Vinzyong that was under construction just nine days before it would have to be put into operation. The cause of collapse came in the deviation from the design solution for the reinforcement of the reinforced concrete columns: instead of six working rods with the diameter of $16 \mathrm{~mm}$, five rods with the diameter of $14 \mathrm{~mm}$ were used. In addition, two balconies were attached to the facade of the building, and the roofing of sheet iron was replaced with tiles. The reduction in the bearing capacity of structural elements and the additional load on them led the building to collapse [11].

When operating, buildings are constantly exposed to external influences, especially natural ones.

Unfavorable weather conditions connected with prolonged precipitation reduce the time between repairs for the buildings in operation. Their untimely repairs, especially in the areas of old buildings, reduce the load-carrying capacity of structures and lead buildings to collapse. So, for this reason, in the period of 2013-2017, according to Internet resources, there were five cases of collapses with the human casualties (five people were killed and thirteen were injured).

Economic activities of people have a negative impact on the components of the environment. The impact of such environments causes the development of physicsmechanical and physics-chemical corrosion processes in the construction materials that lead to changes in the properties of materials, redistribution of the internal forces in cross sections of the elements of the outdoor enclosures and the destruction of the protective layer of working reinforcement in the reinforced concrete structures.

Corrosion leading to the destruction of the material of structures and individual structural elements are presented in the Table $2[12,13]$. 
Table 2. Types of corrosion and corrosion processes, leading to the destruction of building structures.

\begin{tabular}{|c|l|l|}
\hline $\begin{array}{c}\text { Types of } \\
\text { corrosion }\end{array}$ & \multicolumn{1}{|c|}{ Corrosion processes } & \multicolumn{1}{c|}{ Influence results } \\
\hline $\begin{array}{c}\text { Chemical } \\
\text { corrosion }\end{array}$ & $\begin{array}{l}\text { Direct chemical interaction of } \\
\text { materials and aggressive media } \\
\text { (gas and liquid). }\end{array}$ & $\begin{array}{l}\text { Irreversible change in the composition of } \\
\text { building materials (the formation of new } \\
\text { substances). }\end{array}$ \\
\hline $\begin{array}{c}\text { Electrochemi } \\
\text { cal corrosion }\end{array}$ & $\begin{array}{l}\text { Contacts of metal structures with } \\
\text { atmospheric environment, } \\
\text { aqueous solutions, moist soils, } \\
\text { and aggressive gases. }\end{array}$ & $\begin{array}{l}\text { The appearance of electric currents as a result } \\
\text { of the corrosion process, which cause } \\
\text { oxidation and reduction processes. }\end{array}$ \\
\hline $\begin{array}{c}\text { Physical and } \\
\text { chemical } \\
\text { corrosion }\end{array}$ & $\begin{array}{l}\text { Interaction of materials of } \\
\text { inorganic origin with an } \\
\text { aggressive environment. }\end{array}$ & $\begin{array}{l}\text { The appearance of internal stresses in the } \\
\text { materials that reach the ultimate in tensile } \\
\text { strength, as a result of the crystallization of } \\
\text { salts or the deposition of corrosion products } \\
\text { in pores and capillaries. }\end{array}$ \\
\hline Bio-corrosion & $\begin{array}{l}\text { Changing the structure under the } \\
\text { influence of vital activity of } \\
\text { microorganisms: bacteria, } \\
\text { actinomycetes, and fungi. }\end{array}$ & $\begin{array}{l}\text { The development of microorganisms, } \\
\text { accompanied by the formation of organic and } \\
\text { inorganic acid products and carbon dioxide. } \\
\text { As a result, mechanical and chemical } \\
\text { disturbances of concrete and stone materials } \\
\text { occur. }\end{array}$ \\
\hline
\end{tabular}

Specificity of the climatic conditions of Vietnam strengthens negative environmental influences on the construction of buildings and structures. Large wind loads with the simultaneous significant mass of precipitation, storms, tsunamis, typhoons and floods create additional stress on the structure of buildings and lead to their collapse. So, according to the Central Committee on Flood Control in Vietnam, in 2017, 8,166 buildings collapsed and 588,139 were in emergency condition. Typhoons and storms carried 2.65 units of livestock and birds with human casualties (385 dead and 664 injured) [14].

Frequent floods leads to water saturation and erosion of the foundations soil, which leads to a partial loss of its strength and entails uneven sediment of a building with its subsequent collapse.

As a result of the humid climate, moisture accumulates in the surface layers of building structures and the nodes of their interfaces that leads to loss of operational properties of buildings.

Earthquakes also belong to the natural factors that affect the reliability and durability of the functioning of buildings. In Vietnam, seismic resistance of buildings and structures corresponds to 4-6.5 points on the Richter scale. The motion of the Earth's surface of such a power excites the vibrations of buildings and structures, and the inertial forces that arise in them lead to the destruction of the bearing elements.

A comprehensive analysis of the consequences of the impact of anthropogenic, natural and technogenic factors on buildings and structures has shown that the reliability and durability of the constructed facilities are influenced in aggregate by all the factors considered.

The classification of the reasons for the collapse of buildings carried out together with the violations committed at all stages of the life cycle of the building object, and the revealed consequences showed that the beginning of the development of one of the destructive factors intensifies the manifestation of the impact of others that creates a synergistic effect leading the buildings to collapse.

To ensure the durability and safety of buildings and the prevention of technogenic accidents and disasters, simultaneously with the qualitative performance of engineering 
surveys, design and construction works, it is required to carry out constant monitoring of the real technical condition of all building structures and engineering equipment of buildings during their operation for timely detection of defects and development of measures aimed at the protection of buildings from destruction.

\section{References}

1. Information on emergency situations that occurred on the territory of the Russian Federation for 9 months of 2017 (http://www.mchs.gov.ru/activities/stats/ CHrezvichajnie_situacii/2017_god, 2017)

2. Tìm kiếm tù̀ khóa sập nhà (https://news.zing.vn/S\%E1\%BA\%ACP-NH\%C3\%80-timkiem.html 2018)

3. Chua đến một năm, hai vu sập vĩa trần đều xảy ra ở các truờng THPT Hà Nội, (http://vtv.vn/trong-nuoc/chua-den-mot-nam-hai-vu-sap-vua-tran-deu-xay-ra-otruong-thpt-tran-nhan-tong-ha-noi-201803201627 35548.htm, 2018)

4. Nhìn lại nhũng vu sập nhà kinh hoàng tại Việt Nam (http://kienthuc.net.vn/doc30s/nhin-lai-nhung-vu-sap-nha-kinh-hoang-tai-viet-nam-667985.html\#p-1, 2018)

5. A. Yu. Butyrin, A. S. Formina, Real Estate: Economics and Management, 2, 75-78 (2016).

6. Chung cu nghiêng phận ngườ nghiêng theo (http://antg.cand.com.vn/Kinh-te-Vanhoa-The-Thao/Chung-cu-nghieng-phan-nguoi-nghieng-theo-290512/, 2018)

7. Sập nhà 3 tầng giũa đêm ở Sài Gòn (https://news.zing.vn/sap-nha-3-tang-giua-dem-osai-gon-post776614.html, 2018)

8. I nguoòi chết và ba người bị thuoong trong vu sập căn nhà 3 tầng (https://baomoi.com/1nguoi-chet-3-nguoi-bi-thuong-trong-vu-sap-can-nha-3-tang/c/ 22066904.epi, 2018)

9. Tòa nhà 5 tầng ở Hà Nội vị sập đổ hoàn toàn (https://thanhnien.vn/thoi-su/toa-nha-5tang-o-ha-noi-bi-do-sap-hoan-toan-432164.html, 2018)

10. Vu sập xưởng keo ở Lê Đình Cẩn tại quận Tân Bình khiến 2 người chết (https://tintucvietnam.vn/vu-sap-xuong-keo-o-le-dinh-can-tan-tao-quan-binh-tankhien-2-nguoi-chet-6522, 2018)

11. Nhà 4 tầng sắp xây xong thì sập đổ do thi công sai so với thiết kế (http://www.doisongphapluat.com/xa-hoi/nha-4-tang-vua-xay-da-sap-do-do-thi-congsai-so-voi-thiet-ke-a63184.html, 2018)

12. I. S. Guchkin, Diagnostics of damage and restoration of operational properties of structures (DIA Publishing House, Moscow, 2001).

13. V. V. Ledenev, Accidents in construction (Tamb. State University of Technology Publishing, Moscow, 2014).

14. Năm 2017 chính phủ hỗ trợ 39959 tấn gạo cứu đói cho 27 tỉnh chịu thiệt hại do bão (http://laodongxahoi.net/nam-2017-chinh-phu-ho-tro-39959-tan-gao-cuu-doi-cho-27luot-tinh-1309013.html, 2018)

15. A. V. Bogoviz, S. V. Lobova, Y. A. Bugai, Advances in Intelligent Systems and Computing, 622, 30-36 (2018)

16. E. S. Dedyukhina, Izvestiya Vuzov. Investments. Building. Real Estate, 4(9), 19-25 (2014) 